J. Product. \& Dev., 24(3): 571-593(2019)

\title{
USING GREEN NANO-PHYTOTECHNOLOGY FOR REMEDIATION OF WATER POLLUTED WITH FLONICAMID
}

M.R. Ramadan; Romeh, A. A. and Muhanna, A.H., Plant Production Department, Faculty of Technology and Development, Zagazig University, Zagazig, Egypt

\section{ABSTRACT}

The preparation of eco-friendly low-cost activated charcoal (Ach),bentonite (Bent), nano zero-valent iron prepared from Marjoram (Mar-nZVI), nano zero-valent iron prepared from Moringa (Mor-nZVI), Mar-nZVI Ach, Mar-nZVI . Bent, Mor-nZVI . Ach, and Mor-nZVI . Bent with and without Plantago major for the removal of flonicamid pesticide from aqueous solution has been investigated. Structure and morphology of Ach, Bent, Mar-nZVI, Mor-nZVI, Mar-nZVI.Ach, Mar-nZVI.Bent, Mor-nZVI.Ach and Mor-nZVI.Bent were characterized by UV spectroscopy , Fourier transform infrared spectroscopy (FTIR), Highresolution transmission electron microscopy (HRTEM), field emission scanning electron microscopy (SEM).

The results showed that, Mar-nZVI .Ach, Mar-nZVI .Bent and Ach have faster flonicamid removal at all treatment periods. The percent removal of flonicamid in the water reached $31.81 \%-99.42$ by Mar-nZVI. Ach, $26.22 \%-100 \%$ by Mar-nZVI . Bent, 28.21\%-100\% by Ach compared with $1.68 \%-46.59 \%$ in water solution without nZVI or adsorbents between 2hours-8days. Flonicamid was removed more quickly in the presence of Plantago major L. plus nZVI.Ach and Bent than that by P. major alone.

The uptake of P. major roots and translocation of P. major leaves in the water polluted with flonicamid were lower efficient in accumulation of flonicamid from water under the treatments of P. major L. plus $n Z V I$ and plus $n Z V I$. Ach and Bent than that by P. major alone.

Conclusively, from these results it be concluded that plantago major L. plus FeNps Ach and Bent plays a major role for the remediation of flonicamid-contaminated water.

Key words: Flonicamid, green nanotechnology, phytoremediation, water. 


\section{INTRODUCTION}

Pesticides are chemical intended to control pests and weeds. They are widely used in agricultural fields to protect the crops from pest damages. Among the pesticides find huge applications in the agricultural fields. However, more than $90 \%$ of the sprayed pesticides reach the destinations other than their targets because they are sprayed over the entire agricultural field. These chemicals reach the water bodies via agricultural run-offs, direct entry from the spray, industrial effluents, and dust (Khatri and Tyagi, 2015), causing decreases the quality of water (Khatri et al., 2016). Also, Residues of pesticides have significant environmental impacts on aquatic ecosystems and mammals (Joo and Cheng, 2006; Maddah and Hasanzadeh, 2017). Flonicamid (IK1220; $\mathrm{N}$-cyanomethyl-4-trifluoromethylnicotinamide), belongs to the pyridine carboxamide group, is also systemic insecticide with selective activity against aphids and whiteflies that are resistant to other insecticides; the main insecticidal mechanism of flonicamid is starvation due to the inhibition of stylet penetration into plant tissues (Morita et al., 2007). Flonicamid is stable to aqueous photolysis, and is stable/very persistent to aqueous hydrolysis; The water phase $\mathrm{DT}_{50}$ is 33.8 days (stable) and the water-sediment $\mathrm{DT}_{50}$ is 40 days (moderately fast) , Flonicamid have water solubility $5,200 \mathrm{mg} / \mathrm{L}$ with low partition coefficient $\left(\mathrm{K}_{\mathrm{ow}} 0.263\right)$, so its high mobility and very low affinity for soils and sediment (EUFootprint, 2011). Flonicamid offers good persistence in plants, i.e., for about 2-3 weeks (Chawla et al., 2018)

Adsorption is effective method for water cleaning applications. Adsorption has been found to be superior to other techniques for water reuse in terms of initial cost, flexibility, and simplicity of design, ease of operation, and insensitivity to toxic pollutants. This process is a surface phenomenon that depends on the number of sites available, porosity and specific surface area of the adsorbent as well as various types of interactions. (Taghizade et al., 2018)

Nanotechnology is the development and utilization of structures with a size range from $1 \mathrm{~nm}$ to about $100 \mathrm{~nm}$ where new physical, chemical and biological properties occur such as extremely small size, high surface area to volume ratio, surface modifiability and excellent magnetic properties (Riu et al., 2006). In recent years, zero-valent iron (ZVI) has been widely applied for treatment of contamination because of its easy accessibility, effective degradation of pollutants, generation of very little waste and secondary pollutants (Joo and Cheng, 2006 and Thompson,2010).

Many researchers have reported the green synthesis of iron nanoparticles using various plant extracts. Biosynthesis of iron nanoparticles (Fe NPs) has been mainly performed using extract of green tea, which is a cheap and local resource. (Hoag et al.,2009) . Fe0/Fe3O4 nanoparticles were successfully 
synthesised using pomegranate (Punica granatum) leaf extract by (Rao et al., 2013). Makarov et al., (2014) reported the synthesis of iron oxide nanoparticles using aqueous extract of Hordeum vulgare and Rumex acetosa.

Due to high surface area, clay minerals, especially 2:1 smectite type, are well known for their sorption properties. High surface area enables bentonite clay to efficiently scavenge chemical species from wastewater (Dimirkou et al., 2002). Adsorption process by activated carbon is the most efficient and promising fundamental approach in the wastewater treatment processes (Ali and Gupta, 2007 and Gupta et al., 2009).

Therefore, the objective of this study was to investigate the effects of green nanotechnology (iron nanoparticles from medicinal plant extracts, $\mathrm{Fe}^{0}$ ), $\mathrm{Fe}^{0}$ supported on bentonite and activated charchol, and $\mathrm{Fe}^{0}$ supported onadsorbents and Plantago major ffor remediation of flonicamid from water.

\section{MATERIALS AND METHODS}

\section{Pesticide and Plant Material}

Flonicamid 50\% W.G., was obtained from the Central Agriculture Pesticide Laboratory, Agriculture Research Center, 7 Nadi EL Said St., Dokki, Giza, Egypt. Broadleaf plantain, Plantago major L. seedlings $(9-12 \mathrm{~cm}$ in height with 4-6 leaves) were collected from Zagazig University, Governorate of Sharkia, Egypt, then transferred to nutrient solution suggested by (Wang, 1986) for one week to acclimation, after that moved to aqueous media, at the rate of one seedling per medium (Romeh and Hendawi, 2017).

\section{Adsorbent Materials used}

Activated charcoal (4-14 mesh) from El Gomhoureya Company, Egypt and bentonite from Sinai Manganese Company,Egypt were used as adsorbent materials. Bentonite was provided primarily as Na-Mt montmorillonite ( $>90 \%)$, the chemical composition was $51.50 \% \mathrm{SiO}_{2}, 21.50 \% \mathrm{Al}_{2} \mathrm{O}_{3}, 1.95 \% \mathrm{Fe}_{2} \mathrm{O}_{3}$, $1.80 \% \mathrm{MgO}, 0.80 \% \mathrm{CaO}$, and $1.80 \% \mathrm{Na}_{2} \mathrm{O}, 1.3 \% \mathrm{~K}_{2} \mathrm{O}$ (Abd-El-All et al., 1992). After drying overnight at $80{ }^{\circ} \mathrm{C}$, the raw bentonite was ground and sieved through a 200-mesh screen prior to use in experiments.

\section{Synthesis of nano zero-valent iron (nZVI) and supported nZVI}

The nano zero-valent iron prepared from Marjoram (Mar-nZVI) and Moringa (Mor-nZVI) supported on activated charcoal (Ach), and bentonite (Bent) were prepared according to the method described by (Abbassi et al., 2013).

For the synthesis of Mar-nZVI Ach, Mar-nZVI Bent, Mor-nZVI Ach, and Mor-nZVI Bent, $20 \mathrm{~g}$. of each dry Marjoram (Origanum majorana L) and 
Moringa (Moringa oleifera Lam) leaves powdered were heated up to $80^{\circ} \mathrm{C}$ in $1 \mathrm{~L}$ deionized water and filtered using a vacuum filter. A solution of $0.1 \mathrm{M} \mathrm{FeCl}_{3}$ was prepared by dissolving solid $\mathrm{FeCl}_{3}$ in $1 \mathrm{~L}$ of deionized water. This solution was further added into $20 \mathrm{~g}$ of each bentonite (Bent) and activated charcoal (ACh). Subsequently, each prepared extract was added to the mixture of Bent or $\mathrm{ACh}$ and $\mathrm{FeCl}_{3}$ at a 1:2 ratio (v/v). The resultant mixture was mixed for $1 \mathrm{~h}$ using a stirrer. After mixing, the mixture was centrifuged at $5000 \mathrm{rpm}$ for 30 min and washed three times with ethylene to remove the residual ferric chloride. The wet paste was then dried in an oven at $60{ }^{\circ} \mathrm{C}$ overnight, and the final product was grinded before use in the experiment. Mar-nZVI and MornZVI were prepared by a similar procedure as described above without supported material.

\section{Characterization and measurements of zero-valent iron (nZVI) and supported $n Z V I$}

The formation and stability of iron nanoparticles (FeNps) was done by using UV-vis spectrophotometer (Version 530). The absorption spectrum of reaction solutions were recorded at wavelengths ranging from 200 to $500 \mathrm{~nm}$ (Narayan and Park 2014).

The morphology, size and shape of $\mathrm{F}_{-} \mathrm{Fe}^{0}$ were performed by Highresolution transmission electron microscopy (HRTEM), JOEL model JEM2100 using an accelerating voltage of $200 \mathrm{kV}$. Sample preparation for TEM analysis involves depositing a drop of aqueous $\mathrm{F}-\mathrm{Fe}^{0}$ suspension on a carboncoated copper grid and allowed to dry at room temperature; the transmission electron micrographs is used for recording the particle size and morphology. HRTEM Samples were determined at Al-Azhar University.

The FEI Quanta 250 FEG Scanning electron microscopy (SEM) was used for surface morphological and structural studies of B, B-nZVI, Ach, and Ach-nZVI. Images of various materials were obtained at an operating voltage of $30 \mathrm{kV}$.

A Fourier-transform infrared spectroscopy (FT-IR) was used to demonstrate the chemical component of adsorbent material and nanoparticles supported on adsorbent material before and after the reaction with flonicamid between $4000-400 \mathrm{~cm}-1$. After sample preparation, mix with potassium Bromide $(\mathrm{KBr})$ for the extent of $\mathrm{OH}$ signature.

\section{Experimental design}

The potential of Mar-nZVI and Mor-nZVI supported on two adsorbent materials (Ach and Bent) with and without Plantago major for removing flonicamid from aqueous solution $(100 \mathrm{ml})$ at an initial concentration of 20 
$\mathrm{mg} / \mathrm{L}$ were evaluated. Sixteen treatments were prepared in a randomized design, and each treatment consisted of three replicates as follow: (1) Flonicamid-contaminated water with no plants, (2) Flonicamid-contaminated water with a $P$. major seedling,

(3-4) Flonicamid-contaminated water amended with $0.2 \mathrm{~g}$ of Bent and Ach, individually. (5-8) Flonicamid-contaminated water amended with MarnZVI and Mor-nZVI separately, with and without a $P$. major. (9-16) Flonicamid-contaminated water amended with Mar-nZVI ach, Mar-nZVI Bent, Mor-nZVI Ach and Mor-nZVI Bent separately, with and without a P. major.

\section{Sample treatment and analysis}

After 24 hours, 1, 2, 4 and 8 days post treatment, Plant roots from the water were rinsed in running tap water then blotted, $5 \mathrm{~g}$ of leaves, $5 \mathrm{~g}$ of roots and $10 \mathrm{ml}$ of water were analyzed for the determination of flonicamid residues by high-performance liquid chromatography (HPLC).

Flonicamid extracted from water using the the quick, easy, cheap, rugged and safe, QuEChERS (Anastasias, 2003) by placing $10 \mathrm{ml}$ of water into a $50 \mathrm{~mL}$ polypropylene disposable centrifuge tube, adding $20 \mathrm{~mL}$ acetonitrile, vortexing for $1 \mathrm{~min}$ followed by addition of $4 \mathrm{~g}$ magnesium sulphate, $1 \mathrm{~g}$ sodium chloride, $1 \mathrm{~g}$ sodium citrate tribasic (SCT) and $0.5 \mathrm{~g}$ sodium hydrogen citrate sesquihydrate (SHS) and shaking thoroughly for $1 \mathrm{~min}$. Each sample was then centrifuged for 5 min at $3000 \mathrm{rpm}$. A 4-mL aliquot of the resulting acetonitrile supernatant was transferred for analysis of flonicamid by HPLC. Fresh root and leaf samples were chopped, mixed well, and then homogenized with dry ice using a high-speed blender. Extraction and cleanup were conducted using QuEChERS method introduced by (Lehotay et al., 2010) and modified as follows: Finely samples (5 g) were weighed into $50 \mathrm{~mL}$ Teflon centrifuge tubes; $8 \mathrm{~mL}$ of acetonitrile and $2 \mathrm{~mL}$ of methanol were added together and the samples were shaken vigorously for 1 min by shaker to ensure the solvent interacted well with the entire samples. The sample tubes were then stored in a refrigerator at $-20^{\circ} \mathrm{C}$ for $20 \mathrm{~min}$. After that, $4 \mathrm{~g}$ $\mathrm{MgSO}_{4}$ and $1 \mathrm{~g} \mathrm{NaCl}$ were added and the samples were vortexed immediately for $1 \mathrm{~min}$. The extracts were then centrifuged for $5 \mathrm{~min}$ at $5000 \mathrm{rpm}$. From the upper layer of the prepared sample, $2 \mathrm{~mL}$ of the samples were transferred into a $10 \mathrm{~mL}$ tube containing $25 \mathrm{mg}$ PSA sorbent, $125 \mathrm{mg} \mathrm{MgSO}_{4}$ and the samples were again vortexed for $1 \mathrm{~min}$ and then centrifuged for $5 \mathrm{~min}$ at $5000 \mathrm{rpm}$. The obtained residue was finally filtered using a $0.22 \mu \mathrm{m}$ Nylon syringe filter for HPLC analysis.

The operating parameters were as follows: $\mathrm{C}_{18}$ reversed-phase column was used $(250 \times 4.0 \mathrm{~mm}$ i.e. $)$, mobile phase consisted of $100 \%$ acetonitrile with isocratic mode at a flow rate of $0.5 \mathrm{~mL} / \mathrm{min}$, and UV detection at $270 \mathrm{~nm}$. The injection volume was $10 \mu \mathrm{L}$ for quantitative analysis. The retention time of 
flonicamid was $2.80 \mathrm{~min}$. The removal efficiency of flonicamid was calculated as follows:

Removal $(\%)=\left(\mathrm{C}_{0}-\mathrm{C}_{\mathrm{e}}\right) / \mathrm{C}_{0} \times 100$ where $\mathrm{C}_{0}$ and $\mathrm{C}_{\mathrm{e}}$ are the concentration of flonicamid at initial post treatment of each period $\mu \mathrm{g} / \mathrm{ml}$, or $\mu \mathrm{g} / \mathrm{g}$.

\section{RESULTS AND DISCUSSION}

\section{Characterization}

The surface plasmon resonance (SPR) peaks were recorded at 342nm and $341 \mathrm{~nm}$, respectively, for FeNps from Origanum majorana L and Moringa oleifera Lam (Fig. 1), causing the synthesis of FeNps in the size from 2 to 100 nm (Bar et al., 2009; Philip et al., 2011 and Mittal et al., 2013).
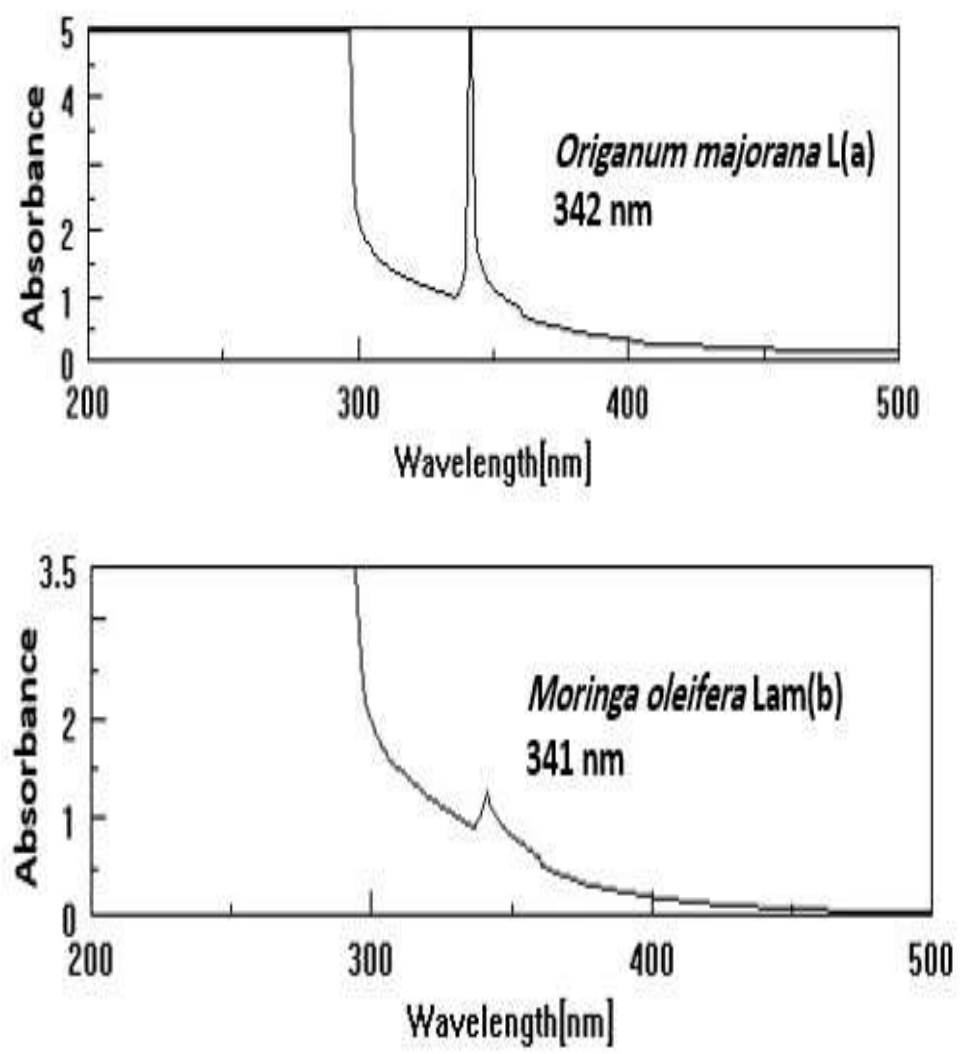

Figure (1). UV-visible spectroscopy of iron nanoparticles (FeNps) synthesized with two medicinal plant leaf extracts in $0.1 \mathrm{M} \mathrm{FeCl}{ }_{3}$ solution. (a) Marjoram -FeNps. (b) Moringa - FeNps. 
The Scanning Electron Microscopic (SEM) images of adsorbents (ads) and nZVI ads showed the morphology and nanoparticle distribution of nZVI on activated charcoal $(\mathrm{ACH})$ and bentonite (Bent) (Figure 1). The active charcoal have a pore and irregular structure form (Figure 2, A) and when the nanos are added, the shape is taken close to the ring (Figure 2, B, C). The diameters of the nano zero-valent iron prepared from Marjoram supported on activated charcoal (Mar-nZVI ach) were in the range of $37.77 \mathrm{~nm}-82.36 \mathrm{~nm}$ compared with $61.52 \mathrm{~nm}-91.89 \mathrm{~nm}$ in nano zero-valent iron prepared from Moringa (Morsupported on activated charcoal (Mor-nZVI ach) (Fig2,B,C).On the other hand, Bentonite is arranged in the form of sheets (Fig2,D) and when the addition of synthesized nZVI supported on Bent has changed to the shape close to the ring(Figure 2, E, F). The diameters of the nano zero-valent iron prepared from Marjoram supported on bentonite (Mar-nZVI Bent) were in the range of 37.77 $\mathrm{nm}-115.3 \mathrm{~nm}$ compared with $51.32 \mathrm{~nm}-87.94 \mathrm{~nm}$ in nano zero-valent iron prepared from Moringa (Mor- supported on bentonite (Mor-nZVI Bent) (Figure 2, E, F). Methods such as scanning electron microscopy (SEM), in view of their ability to directly view the micro-structure of activated carbons have demonstrated enormous potential for use in the study and characterization of activated carbons [Achaw and Afrane, 2008].Several research studies the role of Ach and Bent for remediation of pollutants from water (Amorim et al., 2013 and Rajak et al., 2018).

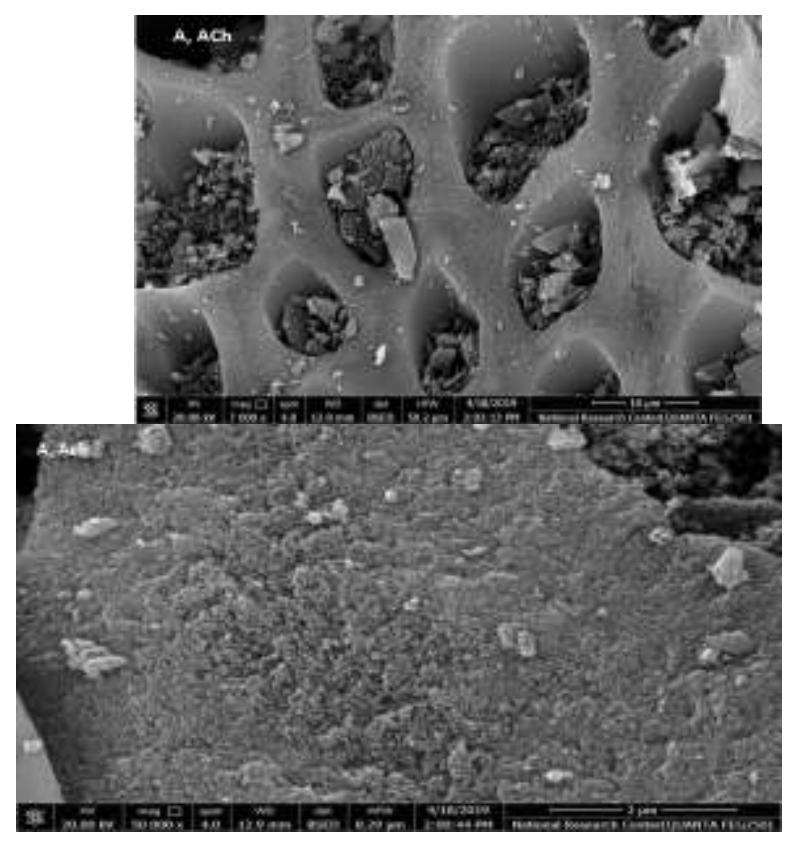




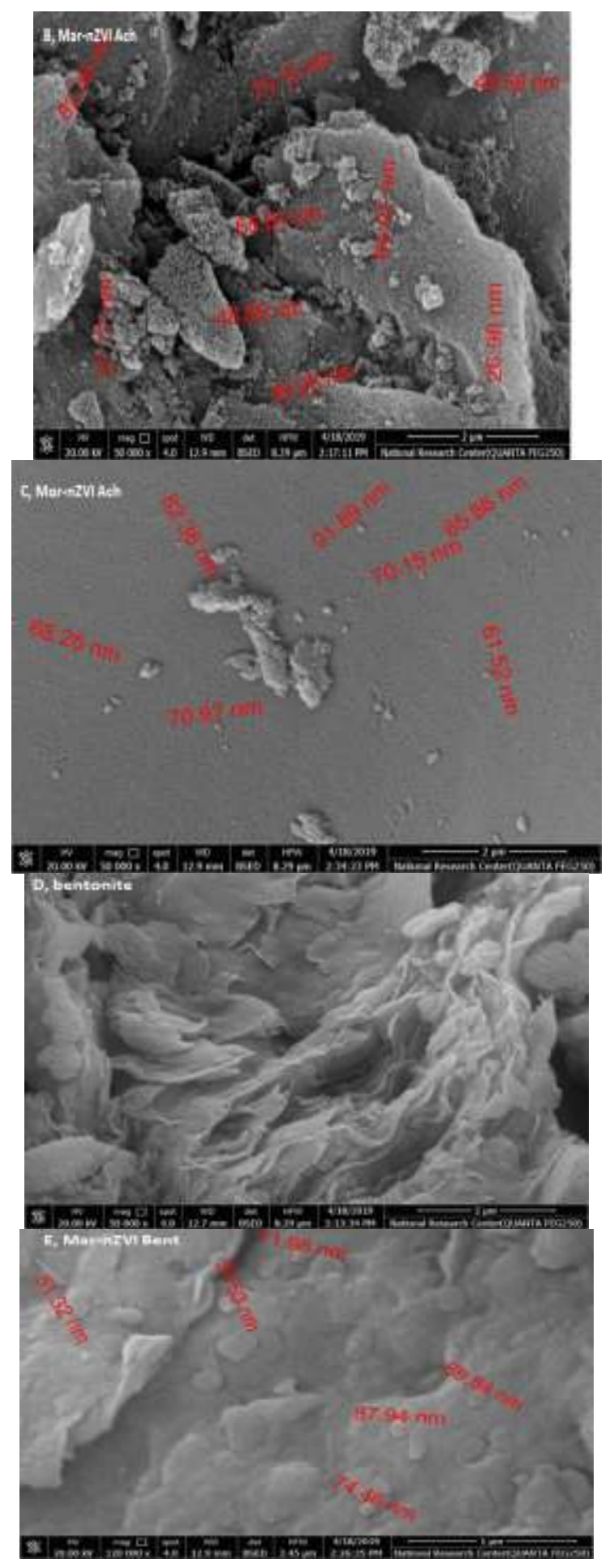




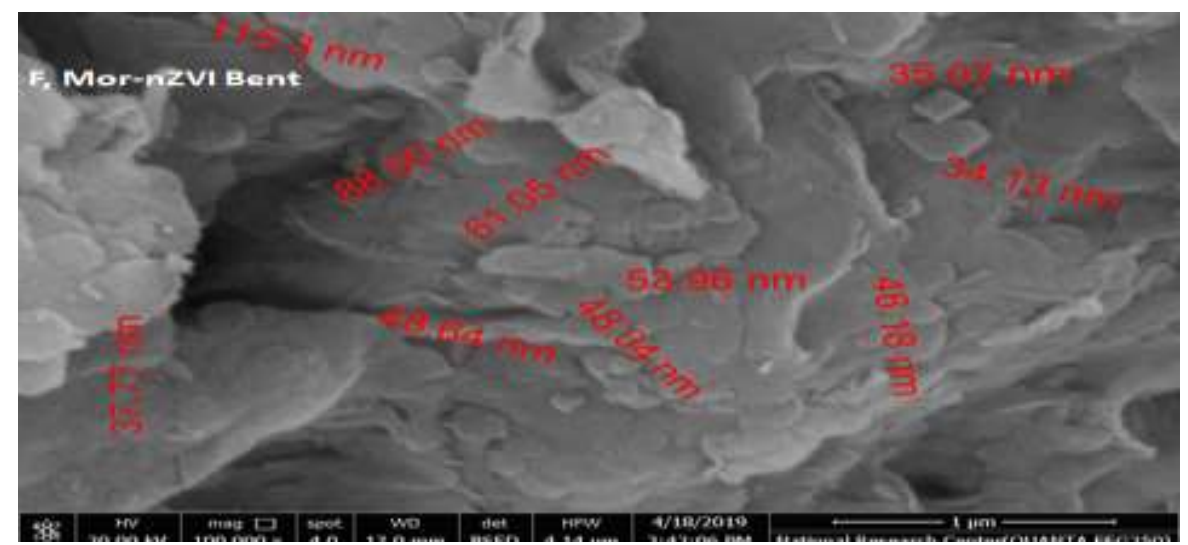

Figure(2). Scanning Electron Microscopic (SEM) for nano zero-valent iron supported on Adsorbents.A-C, represents activated charcoal (ACh), nano zero-valent iron prepared from Marjoram supported on ativated charcoal (Mar-nZVI Ach) and zero-valent iron prepared from Moringa supported on ativated charcoal (Mor-nZVI Ach). D-F represents, bentonite (Bent), nano zero-valent iron prepared from Marjoram supported on bentonite (Mar-nZVI Bent) nano zero-valent iron prepared from Moringa (Morsupported on bentonite (Mor-nZVI Bent)

The analysis of electron microscopy shows that the formed nanoparticles of nano zero-valent iron prepared from Marjoram (Mar-nZVI), and B, zerovalent iron prepared from Moringa (Mor-nZVI) were circular shapes and sizes. The Mar-nZVI and Mor-nZVI were well separated and there was no agglomeration. The shapes of nanoparticles were circular, with sizes lower than 100nm (Figure 3a, b).

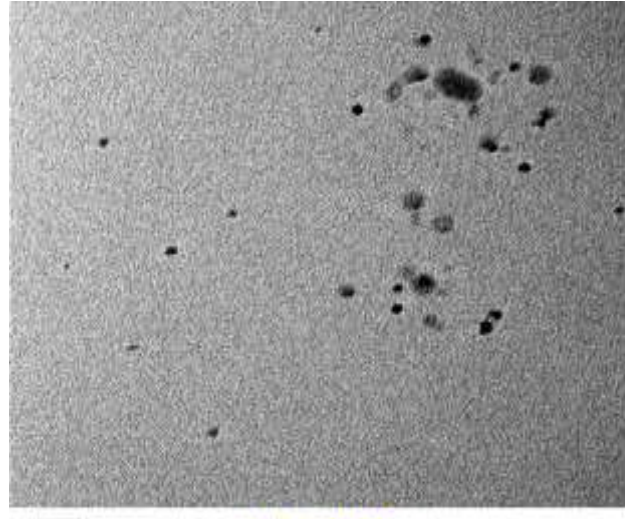

$\overline{\operatorname{con}}=$

A, Mar-nzVI

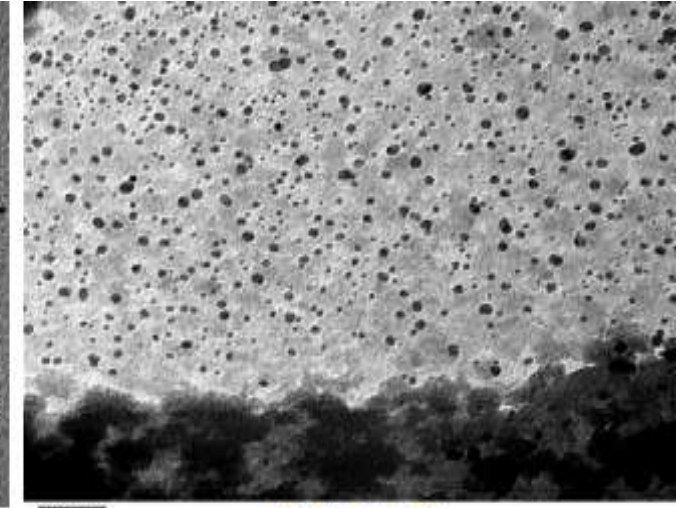

B, Mor-nzVI

Figure (3). High-resolution transmission electron microscopy (HRTEM).A, nano zerovalent iron prepared from Marjoram (Mar-nZVI), and B, zero-valent iron prepared from Moringa(Mor-nZVI). 


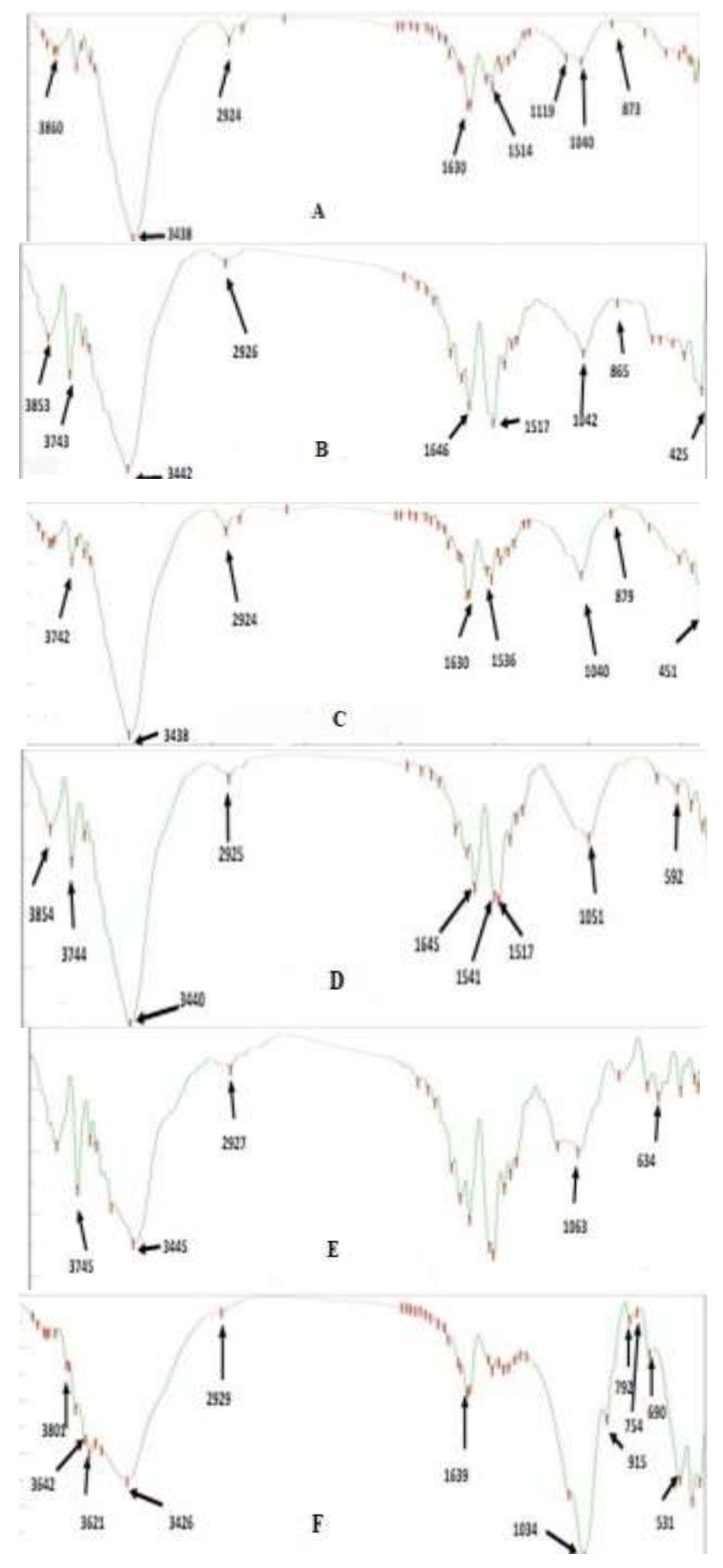




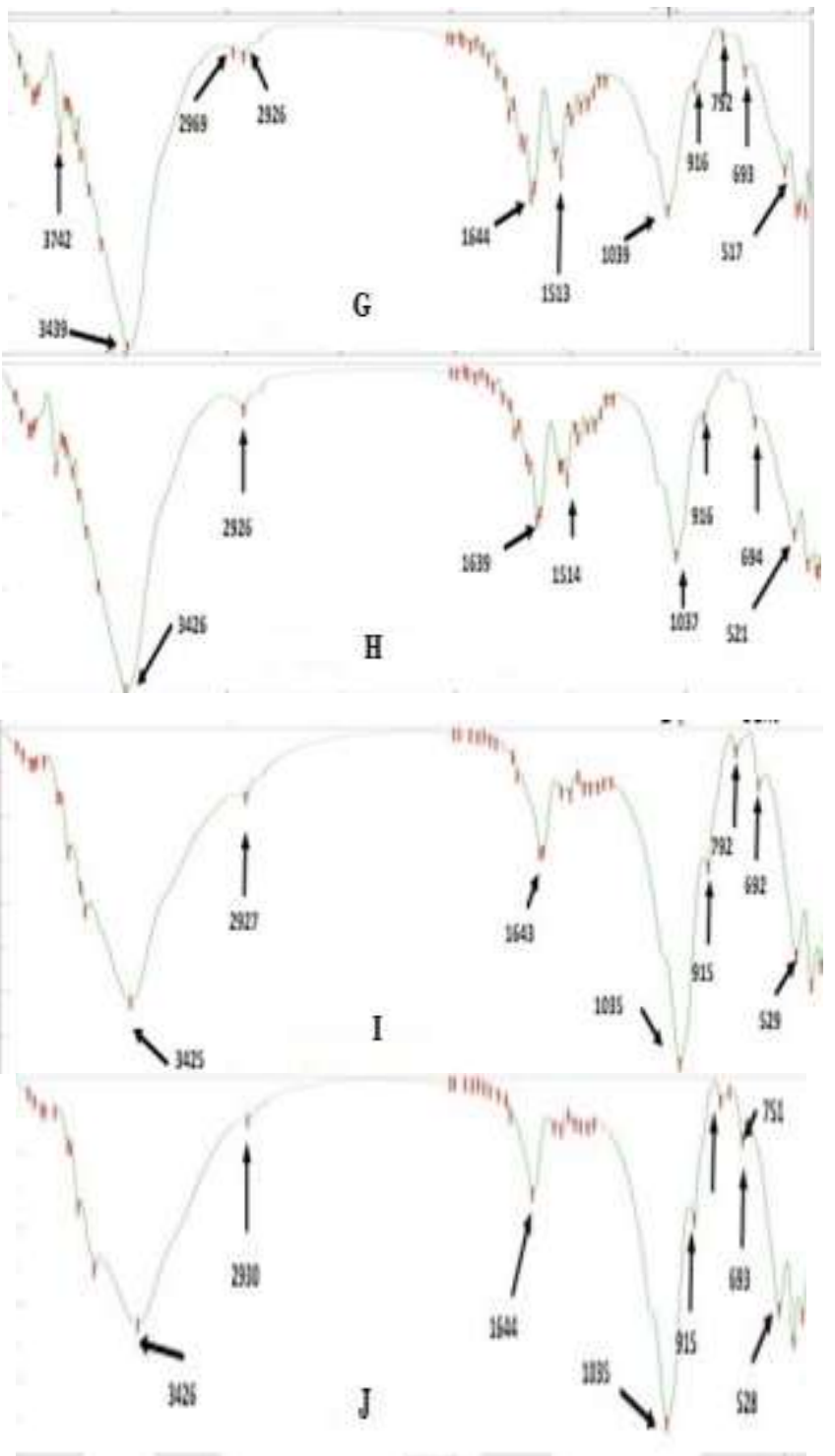

Figure (4). A Fourier-transform infrared spectroscopy (FT-IR) for adsorbents (Ach and Bent, nano zero-valent iron supported on adsorbents and nano zerovalent iron supported on adsorbents plus flonicamid.(A).Ach (B).MarnzvI-Ach (C).flonicamid+Mar-nzvI-Ach (D).Mor-nzvI-Ach (E). flonicamid+Mor-nzvI-Ach $\quad$ (F).Bent $\quad$ (G).Mar-nzvI-Bent (H).flonicamid+Mar-nzvI-Bent (I).Mor-nzvI-Bent (j). flonicamid+MornzvI-Bent 
The infrared spectra for Ach and Bent, Mar-nZVI ach, Mar-nZVI Bent, Mor-nZVI Ach, and Mor-nZVI Bent after reaction with flonicamids are shown in Fig. 4. Data in FT-IR spectroscopy (Fig. 4) recorded a broad peak at region $3438 \mathrm{~cm}^{-1}$ is assigned to $\mathrm{O}-\mathrm{H}$ stretching vibration of hydrogen bonded hydroxyl groups (ahmed and hameed,2009 and Valente Nabais et al., 2011). The band at $2924 \mathrm{~cm}^{-1}$ denotes the $\mathrm{C} \equiv \mathrm{C}$ stretching vibrations in alkyne groups, while the peak wavelength at $1630 \mathrm{~cm}^{-1}$ is caused by the $\mathrm{C}=\mathrm{O}$ stretching band of the carboxyl group or alkene $\mathrm{C}=\mathrm{C}$ stretching vibration in aromatic rings (Yang and qiu,2010). The absorption peak at $1514 \mathrm{~cm}^{-1}$ is recorded to the $\mathrm{C}-\mathrm{C}$ stretch. The band that appears near $1040 \mathrm{~cm}^{-1}$, represents indicates the existence of $\mathrm{C}-\mathrm{O}$ stretching vibrations in alcohols, phenols, acids, ethers or esters (Figueiredo et al., 1999 and Tongpoothorn et al., 2011). Also, the absorption peak at $873 \mathrm{~cm}^{-1}$ is showed to the C-halogen stretches. After loading zerovalent iron prepared from marjoram supported on activated charcoal (MarnZVI Ach), there is a shift in the absorption band of 3,438-3,426 $\mathrm{cm}^{-1}, 2,924$ $2,926 \mathrm{~cm}^{-1}, 1,630-1,646 \mathrm{~cm}^{-1}, 1,514-1,517 \mathrm{~cm}^{-1}, 1,040-1,042 \mathrm{~cm}^{-1}$, and 873$865 \mathrm{~cm}^{-1}$, while after loading zero-valent iron prepared from moringa supported on ativated charcoal (Mor-nZVI Ach), there is a shift in the absorption band of $3,438-3,440 \mathrm{~cm}^{-1}, 1,630-1,645 \mathrm{~cm}^{-1}, 1,514-1,517 \mathrm{~cm}^{-1}$ and $1,040-1,051 \mathrm{~cm}^{-1}$. The reaction of flonicamid with Mar-nZVI Ach induced some modifications of the infrared spectra. There is a shift in the absorption band of, 1,514-1,536 $\mathrm{cm}^{-1}$ and $873-879 \mathrm{~cm}^{-1}$ while the reaction of flonicamid with Mor-nZVI Ach caused shift in the absorption band of 3,438-3,445 $\mathrm{cm}^{-1}, 1,630-1,646 \mathrm{~cm}^{-1}, 1,514$ $1,517 \mathrm{~cm}^{-1}$ and $1,040-1,063 \mathrm{~cm}^{-1}$.

The FTIR spectrum specifies the physic-sorption and chemi-sorption of the flonicamid onto the bentonite due to the existence, shift or disappearance of the peaks of functional groups (Fig. 4). FT-IR spectroscopy (Fig. 4)

The bands at $3642 \mathrm{~cm}^{-1}$ and $3624 \mathrm{~cm}-1$ were assigned to $1-\mathrm{Mg}-\mathrm{OH}$ stretching and $\mathrm{Al}-\mathrm{Al}-\mathrm{OH}$ stretching respectively. Al-Al-OH bending vibrations band at $916 \mathrm{~cm}-1$ and Al-Fe-OH bending vibrations at $795 \mathrm{~cm}-1$ were typical of bentonite clays. Consequently, the bentonite utilized in the present study was rich in aluminum and contained a portion of magnesium and iron too (Sikdar et al., 2008). The Si-O stretching band was seen at 1031.The broad peak at region $3426 \mathrm{~cm}^{-1}$ was recorded indicates the possible presence of alcohol - $\mathrm{O}-\mathrm{H}$, Phenol -OH group, or-NH groups in Bent. The absorption peak at $2929 \mathrm{~cm}^{-1}$ is recorded to the $\mathrm{C}-\mathrm{C}-\mathrm{H}, \mathrm{C}=\mathrm{C}-\mathrm{H}$. Also, observed bands wavelength at $1639 \mathrm{~cm}^{-1}$ was assigned to the - $\mathrm{OH}$ bending vibrations of water adsorbed in the bentonite (Dutta and Singh 2015 and Shehata et al., 2016). The band that appears near $1034 \mathrm{~cm}^{-1}$, represents Si-O stretching band and the absorption peak at $531 \mathrm{~cm}^{-1}$ was allotted to the Si-O bending vibration.. After loading zero-valent iron 
prepared from marjoram supported on bentonite (Mar-nZVI Bent), there is a shift in the absorption band of 3,426-3,439 $\mathrm{cm}^{-1}, 2,929-2,926 \mathrm{~cm}^{-1}, 1,639-$ $1,644 \mathrm{~cm}^{-1}, 1,034-1,039 \mathrm{~cm}^{-1}, 915-916 \mathrm{~cm}^{-1}, 690-693 \mathrm{~cm}^{-1}$ and $531-517 \mathrm{~cm}^{-1}$, while after loading zero-valent iron prepared from moringa supported on bentonite (Mor-nZVI Bent), there is a shift in the absorption band of 3,426$3,427 \mathrm{~cm}^{-1}, 2,929-2,927 \mathrm{~cm}^{-1}, 1,639-1,643 \mathrm{~cm}^{-1}, 1,034-1,035 \mathrm{~cm}^{-1}, 690-692$ $\mathrm{cm}^{-1}$ and $531-529 \mathrm{~cm}^{-1}$ and $531-529 \mathrm{~cm}^{-1}$. The reaction of flonicamid with MarnZVI bentonite induced some modifications of the infrared spectra. There is a shift in the absorption band of, 3,426-3,439 $\mathrm{cm}^{-1}, 2,929-2,926,915-916 \mathrm{~cm}^{-1}$,

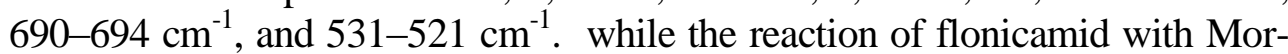
nZVI Bent caused shift in the absorption band of $2,929-2,930 \mathrm{~cm}^{-1}, 1,639$ $1,644 \mathrm{~cm}^{-1}, 1,034-1,035 \mathrm{~cm}^{-1}, 792-791 \mathrm{~cm}^{-1}, 690-693 \mathrm{~cm}^{-1}$ and $531-528 \mathrm{~cm}^{-}$ 1 and $531-528 \mathrm{~cm}^{-1}$.

\section{Remediation of water polluted by floncamid by nZVI supported on adsorbents}

The preparation of eco-friendly low-cost activated charcoal (Ach), bentonite (Bent), nano zero-valent iron prepared from Marjoram (Mar-nZVI), nano zero-valent iron prepared from Moringa (Mor-nZVI), Mar-nZVI supported on Ach, Mar-nZVI supported on Bent, Mor-nZVI supported on Ach, and Mor-nZVI supported on Bent with and without Plantago major for the removal of flonicamid pesticide from aqueous solution has been investigated in Figures 5 and 6.

The results showed that Mar-nZVI supported on Ach, Mar-nZVI supported on Bent and Ach have faster floncamid removal at all treatment periods, this attributed to the adsorptive capacity of Ach and presence of the adsorbents, Ach and Bent in the composite have served in decreasing the aggregation of the nZVI chains and thereby resulted in higher surface activity of the nanoparticles, and therefore faster flonicamide removal (Shi et al., 2011; Wang et al., 2013 and Reyes et al., 2014). The percent removal of flonicamid in the water reached $31.81 \%$ - 99.42 by Mar-nZVI supported on Ach, 26.22\%$100 \%$ by Mar-nZVI supported on Bent, and $28.21 \%-100 \%$ by Ach compared with $1.68 \%-46.59 \%$ in water solution without nZVI or adsorbents between 2hours-8days (Figure 6). Studies have shown that many pesticides can be destroyed using ZVI. It also has been successfully used in dechlorination of highly recalcitrant pesticides and herbicides (Doong and Lai,2006 and Sayles et al., 1997). When halogenated organic pollutants are treated with ZVI, oxidation of ZVI and $\mathrm{Fe}(\mathrm{II})$ provides electrons for dechlorination (Satapanajaru et al., 2008). Young-Soo et al., (2003) studied the reduction of eleven nitroaromatic pesticides with zero-valent iron powder. Shi et al., (2011) tested nanoparticles 


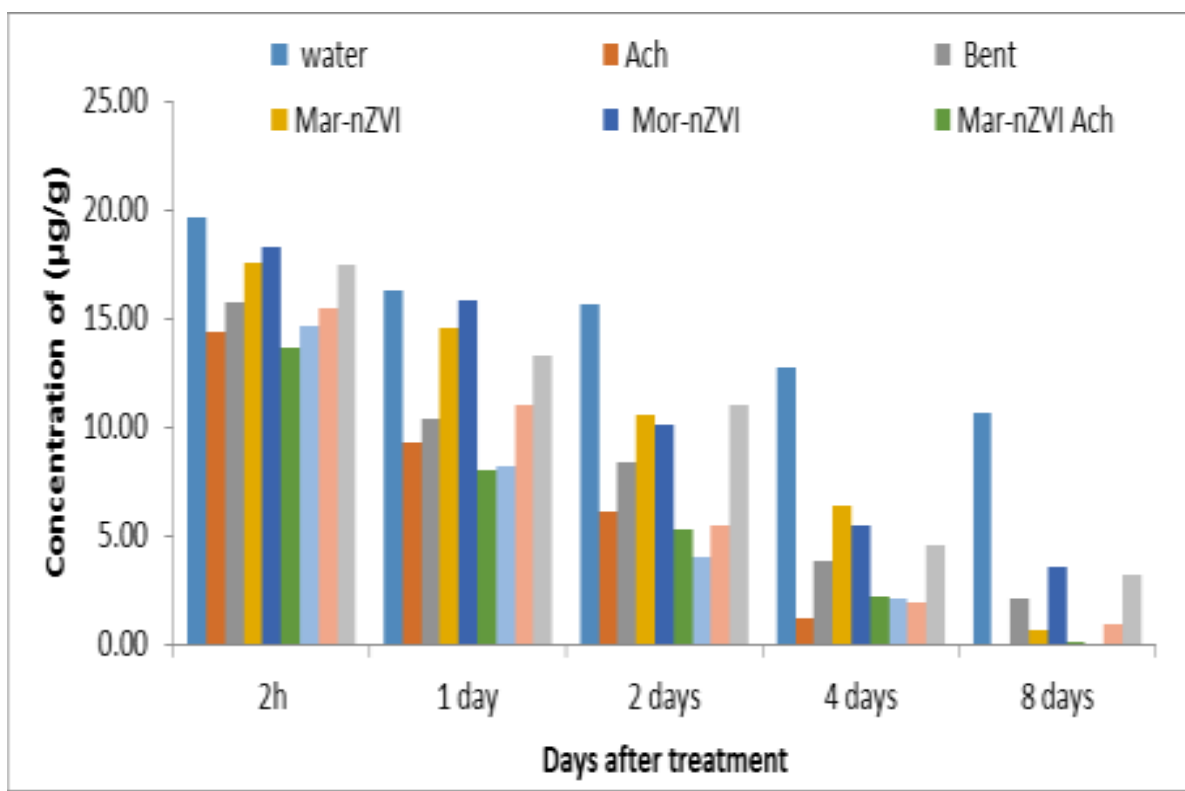

Figure (5). Degradation of flonicamid in water by zero-valent iron nanoparticles supported on different adsorbent materials (nZVI ads).

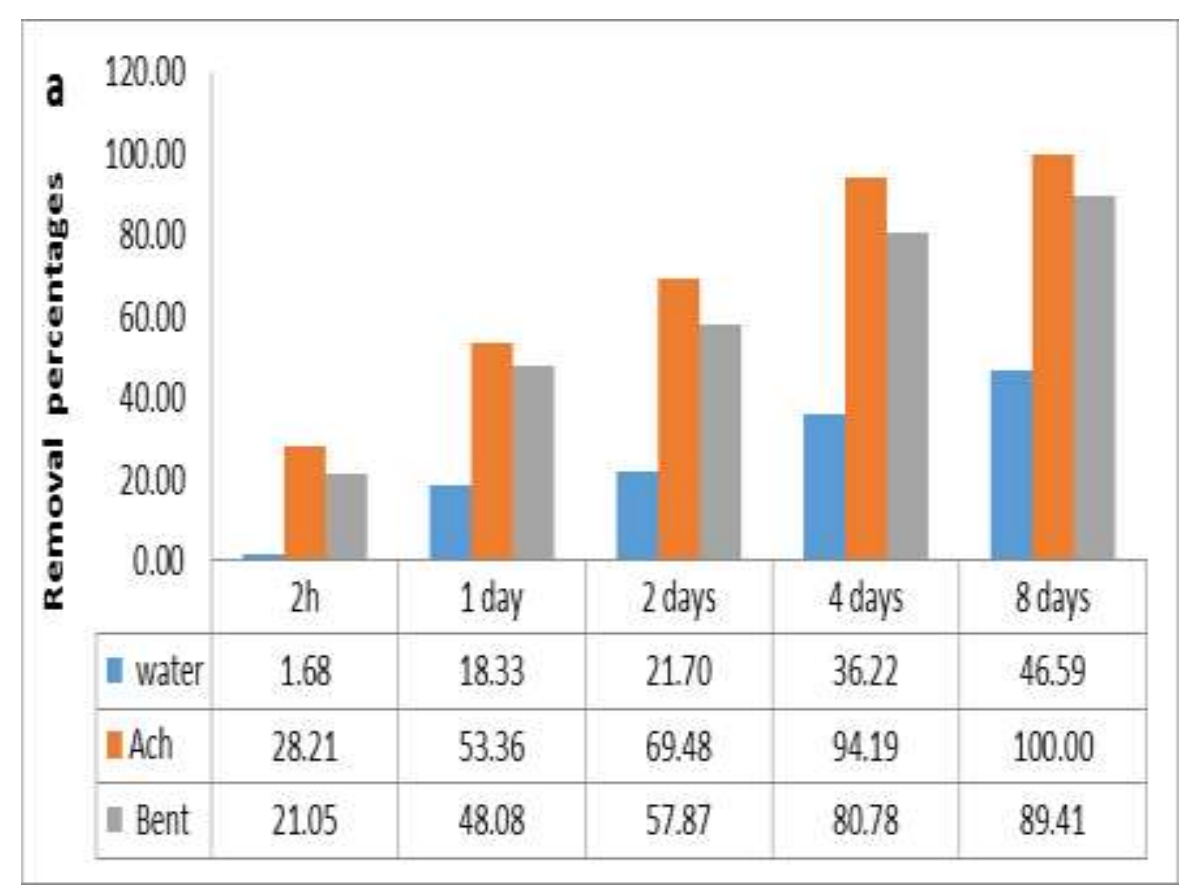




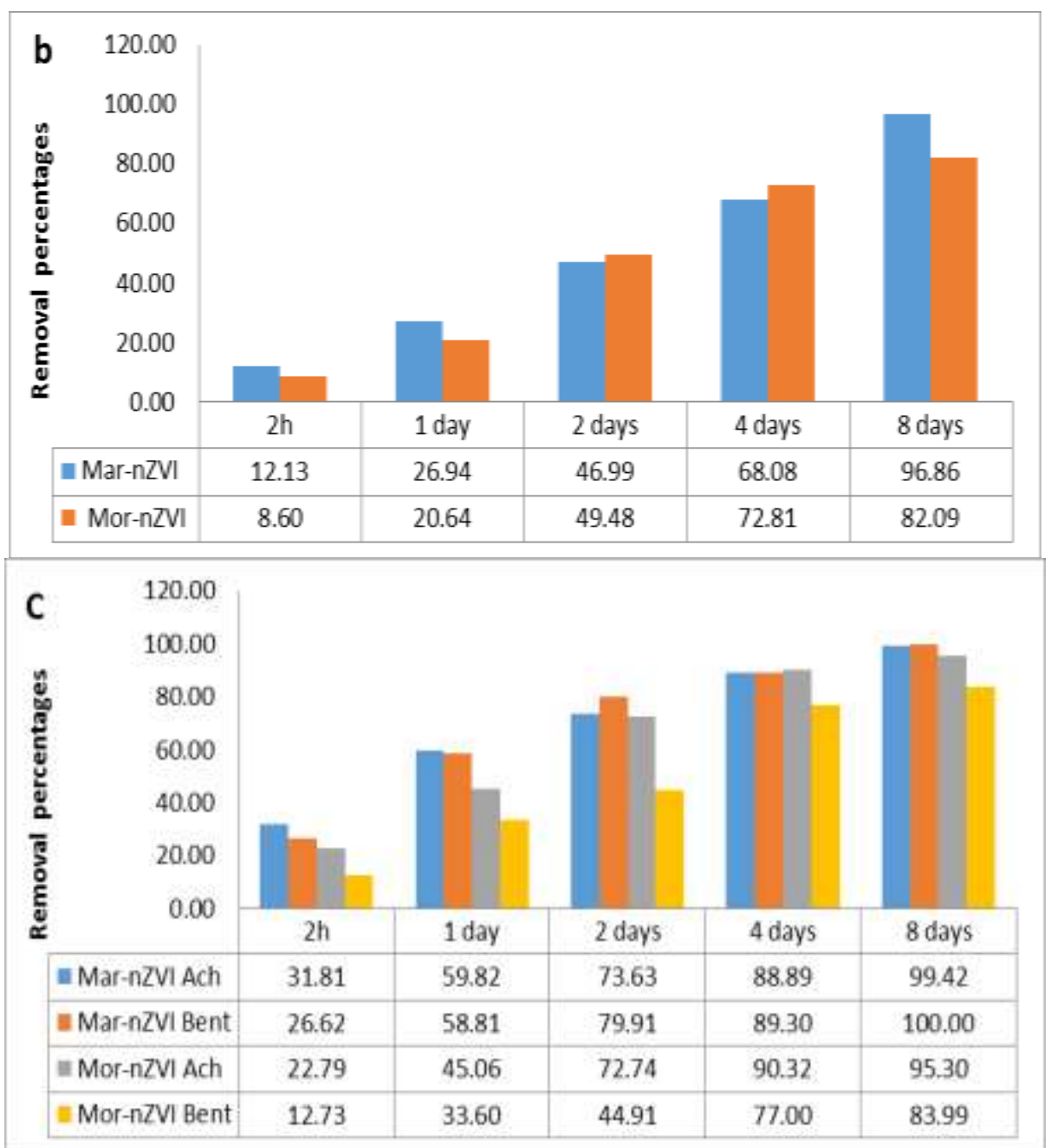

Figure (6). Percent removal of flonicamid in water by zero-valent iron nanoparticles supported on different adsorbent materials (nZVI ads).

zero-valent iron (nZVI), and iron nanoparticles zero valence on a matrix of bentonite (B-nZVI), in the removal of $\mathrm{Cr}$ (VI) in water and soil solution contaminated with this metal. The removal of other pollutants such as chlorinated organic compounds, pesticides, phenols, amines, and organic acids through such nanoparticles has been studied (Wang et al., 2013). Polymer-clay nanocomposites have received a great deal of attention, including studies on developing the composites as sorbents for nonionic and anionic pollutants (Churchman, 2002), organic pollutants (Breen, 1999), anionic herbicide (Radian and Mishael, 2008), and atrazine (Zadaka et al., 2009). 
Ach is good potential to remove various types of pesticides. The adsorption capacity of pollutants by Ach may involve one or more mechanisms, such as hydrophobic effect, covalent bonding, $\pi-\pi$ interactions, hydrogen bonding, and electrostatic interactions (Yang and Xing, 2010 and Pyrzynska, 2011). Adsorption may also take place through hydrogen bonding between functional groups such as - $\mathrm{COOH}$, $\mathrm{OH},-\mathrm{NH} 2$ and organic molecules (LUQUEÑO et al., 2017). Salman et al., (2011) showed that, The banana stalk activated carbon (BSAC) is an efficient adsorbent for the adsorptive removal of 2,4-D and bentazon from aqueous solutions. (BSAC) was characterized by Fourier transform. Infrared spectroscopy (FT-IR) analysis. The adsorption of several organic contaminants in water such as pesticides, phenols, and chlorophenols has been reported recently in the literature (Sanchez Camazano and Sanchez Martin, 1983; Ainsworth et al., 1987; Rodriguez et al., 1988; Shu et al., 1997; Torrents and Jayasundera, 1997; Danis et al., 1998 and Konstantinou et al., 2000).

\section{Nano-Phytotechnological removal of flonicamid polluted water}

Data in Table 1 and Figure 7 showed that flonicamid was removed more quickly in the presence of Plantago major L. plus nZVI and plus nZVI supported on Ach and Bent than that by P. major alone (Table 1). The results indicate that, flonicamid removal efficiency by each nZVI, nZVI supported on adsorbent, nZVI plus $P$. major and nZVI supported on adsorbent plus $P$. major were nearly $100 \%$ (Figure 7 ).

The uptake of $P$. major roots and translocation of $P$. major leaves in the water polluted with flonicamid were lower efficient in accumulation of flonicamid from water under the treatments of $P$. major L. plus nZVI and plus nZVI supported on Ach and Bent than that by $P$. major alone. This is attributed to the role nZVI alone or combined with adsorbents in degradation of flonicamid in water, therefore the concentration of flonicamid was more decreased in the roots and in the leaves of P. major (Table 1). Pillai and Kottekottil, (2016) show that the removal of endosulfan reached $82 \%$ was removed within 7 days when nano phytoremediation experiments were conducted with $A$. calcarata then gradually decreased, probably due to the activity of nZVI decreased over time. In addition, removal efficiency was found to be highest when nano-phytoremediation experiments were conducted in soil with the TNT/nZVI ratio of $1 / 10$ with the complete TNT remediation (initial TNT concentration: $100 \mathrm{mg} / \mathrm{kg}$ ) within 60 days (Jiamjitrpanich et al., 2013). 
Table 1. Degradation of flonicamid in water by zero-valent iron nanoparticles supported on different adsorbent materials (nZVI ads) plus P. major.

\begin{tabular}{|c|c|c|c|c|c|}
\hline \multirow[t]{2}{*}{ Treatments } & \multicolumn{5}{|c|}{ Days after treatments } \\
\hline & $\begin{array}{c}\mathbf{2 h} \\
(\mu \mathrm{g} / \mathrm{g})\end{array}$ & $\begin{array}{c}\begin{array}{l}1 \text { day } \\
(\mu \mathrm{g} / \mathrm{g})\end{array} \\
\end{array}$ & $\begin{array}{c}2 \text { days } \\
(\mu \mathrm{g} / \mathrm{g})\end{array}$ & $\begin{array}{l}4 \text { days } \\
(\mu \mathrm{g} / \mathrm{g})\end{array}$ & $\begin{array}{l}8 \text { days } \\
(\mu \mathrm{g} / \mathrm{g})\end{array}$ \\
\hline \multicolumn{6}{|c|}{ Water } \\
\hline Pantain & 16.21 & 14.40 & 12.44 & 10.92 & 8.83 \\
\hline Mar-nZVI +Plantain & 13.82 & 10.01 & 7.90 & 3.92 & 1.03 \\
\hline Mor-nZVI+Plantain & 15.60 & 12.53 & 6.78 & 2.13 & 0.12 \\
\hline Mar-nZVI Ach+Plantain & 12.10 & 6.36 & 2.98 & 0.79 & 0.31 \\
\hline Mar-nZVI Bent+Plantain & 14.18 & 8.12 & 2.48 & 1.58 & 0.00 \\
\hline Mor-nZVI Ach+Plantain & 13.31 & 8.91 & 1.42 & 1.02 & 0.30 \\
\hline Mor-nZVI Bent+Plantain & 15.37 & 11.53 & 6.92 & 2.65 & 0.03 \\
\hline \multicolumn{6}{|c|}{ Roots } \\
\hline Plantain & 2.02 & 8.01 & 12.20 & 17.45 & 14.81 \\
\hline Mar-nZVI +Plantain & 1.26 & 3.07 & 8.07 & 10.87 & 5.94 \\
\hline Mor-nZVI+Plantain & 3.57 & 5.74 & 10.71 & 13.37 & 3.66 \\
\hline Mar-nZVI Ach+Plantain & 1.03 & 2.68 & 5.80 & 8.74 & 2.38 \\
\hline Mar-nZVI Bent+Plantain & 1.40 & 2.65 & 7.30 & 9.94 & 3.92 \\
\hline Mor-nZVI Ach+Plantain & 3.80 & 4.43 & 6.40 & 8.52 & 1.58 \\
\hline Mor-nZVI Bent+Plantain & 3.93 & 4.16 & 9.19 & 15.77 & 5.98 \\
\hline \multicolumn{6}{|c|}{ Leaves } \\
\hline Plantain & 5.37 & 7.04 & 11.21 & 16.50 & 19.92 \\
\hline Mar-nZVI +Plantain & 2.46 & 5.41 & 9.43 & 11.97 & 16.18 \\
\hline Mor-nZVI+Plantain & 2.23 & 5.59 & 9.83 & 13.09 & 18.91 \\
\hline Mar-nZVI Ach+Plantain & 0.14 & 2.88 & 5.37 & 7.66 & 13.26 \\
\hline Mar-nZVI Bent+Plantain & 3.75 & 4.45 & 6.25 & 9.77 & 14.49 \\
\hline Mor-nZVI Ach+Plantain & 3.59 & 6.24 & 8.02 & 10.11 & 13.61 \\
\hline Mor-nZVI Bent+Plantain & 2.27 & 5.38 & 10.20 & 13.63 & 15.28 \\
\hline
\end{tabular}

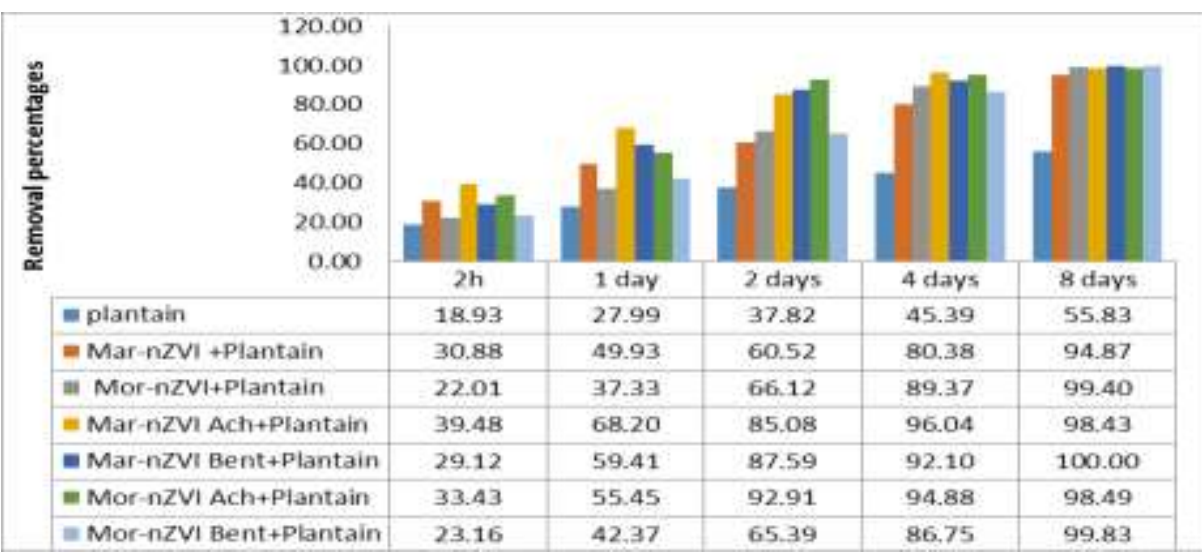

Figure (7). Percent removal of flonicamid in water by zero-valent iron nanoparticles supported on different adsorbent materials (nZVI ads) plus $P$. major. 
Conclusively, from these results it be concluded that plantago major L. plus FeNps Ach and Bent plays a major role for the remediation of flonicamid-contaminated water.

\section{REFERENCES}

Abbassi, R., K.Y. Asheesh, K. Naresh, H. Shan and R.J. Peter (2013). Modeling and optimization of dye removal using"green"clay supported ironnano-particles. Ecological Engineering. 61, 366-370.

Abd-El.All, S.T., M.A.T. Dief and R.R. Shahin (1992) Soil Chemistry. Open Education, Cairo Univ. (Text book in arabic)

Achaw, O.W. and G. Afrane, (2008). The evolution of pore structure of coconut shells during the preparation of cocnut shell-based activated carbons. Microporous and Mesoporous Materials, 112, pp. 284 - 290, ISSN 1387-1811.

Ahmad, A.A. and B.H. Hameed (2009). Reduction of COD and color of dyeing effluent from a cotton textile mill by adsorption onto bamboobased activated carbon, J. Hazard. Mater. 172 1538-1543.

Ainsworth, C. C., J. M. Zachara and R. L. Schmidt (1987).Quinoline sorption on Na-montmorillonite: contributions of the protonated and neutral species," Clays \& Clay Minerals, vol. 35, no. 2, pp. 121-128.

Ali, I. and V.K. Gupta (2007). Advances in water treatment by adsorption technology. Nat. Protoc. 1, 2661e2667.

Anastasias M, S.J. Lehotay, D. tajnbaher and F.J. Schenck (2003). Fast and easy multiresidue method employing acetonitrile extraction/partitioning and "dispersive solid-phase extraction" for the determination of pesticide residues in produce. Journal of AOAC International 86: 412-431

Bar, H., D. Bhui, G.Sahoo, P. Sarkar, S. Pyne, and A.Misra (2009). Green synthesis of silver nanoparticles using seed extract of Jatropha curcas. Colloids and Surfaces A: Physicochemical and Engineering Aspects, 348(1), 212-216.

Breen, C. (1999). The characterisation and use of polycationexchanged bentonites. Applied Clay Science, vol. 15, no. 1-2, pp. 187-219.

Camila C. A., C. B Sue Ellen., Eliza` P. C. Ngela, c. T.Ana Paula and M.D. Mo ${ }^{\wedge}$ Nica Lea $\sim 1$. Journal of Environmental Science and Health, Part $B(2013)$ 48, 183-190. 
Chawla1,S., N. G. Hetal, K. P. Hemlatta, D. P. Kaushik, R. P.Anil, V. Shukla1, M. Ilyas2, K. P.Satish, Somashekar4, R. S. Meena5 and P. G. Shah1(2018). Validation, residue analysis, and risk assessment of fipronil and flonicamid in cotton (Gossypium sp.) samples and soil. Environmental Science and Pollution Research 25:19167-19178.

Churchman, G. J. (2002). Formation of complexes between bentonite and different cationic polyelectrolytes and their use as sorbents for non-ionic and anionic pollutants, Applied Clay Science, vol. 21, no. 3-4, pp. 177-189.

Danis, T. G., T. A. Albanis, D. E. Petrakis and P. J. Pomonis (1998).Removal of chlorinated phenols from aqueous solutions by adsorption on alumina pillared clays and mesoporous alumina aluminum phosphates," Water Research, 32(2): pp. 295-302.

Dimirkou A. Ioannou A. Doula M. (2002) Preparation, characterization and sorption properties for phosphates of hematite, bentonite and bentonitehematite systems. Adv. Colloid Interface 97 (1-3), 37 - 60.

Doong, R. a. and Y. 1. Lai (2006). Effect of metal ions and humic acid on the dechlorination of tetrachloroethylene by zerovalent iron, Chemosphere, 64: 371-378.

Dutta, A. and N. Singh (2015). Surfactant-modified bentonite clays: preparation, characterization, and atrazine removal. Environ. Sci. Pollut. Res., 22(5): 3876-3885.

EUFootprint, (2011). Footprint Pesticide Properties Database. Chlorantraniliprole. University of Hertfordshire.

Fernández-luqueño, F., F.Lopez-valdez, C.R. Sarabia-castillo, S. Garcíamayagoitia and S.R. Perez-rios (2017).Bioremediation of polycyclic aromatic hydrocarbons-polluted soils at laboratory and field scale: a review of the literature on plants and microorganisms. In: Enhancing cleanup of environmental pollutants Vol. 1: Biological approaches, ANJUM N.A., GILL S.S., TUTEJA N. (Eds.), Springer. Switzerland, 43.

Figueiredo, J.L., M.F.R. Pereira, M.M.A.Freitas and J.J.M. $\mathbf{O}^{\prime}$ rfa $^{\sim}$ o (1999). Modification of the surface chemistry of activated carbons. Carbon 37, 1379-1389.

Gupta, V.K., P.J.M. Carrott, M.M.L. Ribeiro Carrott and Suhas (2009). Low cost adsorbents: growing approach to wastewater treatment e a review. Crit. Rev. Environ. Sci. Technol. 39, 783e842.

Hoag, G.E.; J.B. Collins, J.L. Holcomb, J.R. Hoag, M.N. Nadagouda and R.S. Varma (2009).Degradation of bromothymol blue by 'greener' nano-scale zero-valent iron synthesized using tea polyphenols. J. Mater. Chem., 19, 8671-8677. [CrossRef] 
Jiamjitrpanich, W., P. Parkpian, C. Polprasert and R. Kosanlavit (2013). Trinitrotoluene and Its Metabolites in Shoots and Roots of Panicum Maximum in Nano-Phytoremediation. International Journal of Environmental Science and Development (IJESD) 4: 7-10.

Joo, S. H. and F. Cheng (2006). "Nanotechnology for environmental remediation", Springer Science \& Business Media.

Khatri, N. and S.Tyagi (2015). Influences of natural and anthropogenic factors on surface and groundwater quality in rural and urban areas. Front. Life Sci. 8, 23e39.

Khatri, N., S. Tyagi and D. Rawtani, (2016). Assessment of drinking water quality and its health effects in rural areas of Harij taluka, Patan district of northern Gujarat. Environ. Claims J. 28 (3), 223e246

Konstantinou, I. K., T. A. Albanis, D. E. Petrakis and P. J. Pomonis (2000). Removal of herbicides from aqueous solutions by adsorption on Alpillared clays, Fe-Al pillared clays and mesoporous alumina aluminum phosphates," Water Research, vol. 34, no. 12, pp. 3123-3136.

Lehotay S.J., K.A. Son, H.Y. Kwon, U, Koesukwiwat, W. Fu, K. Mastovska, E. Hoh and N. Leepipatpiboon (2010) Comparison of $\mathrm{QuEChERS} \mathrm{sample} \mathrm{preparation} \mathrm{methods} \mathrm{for} \mathrm{the} \mathrm{analysis} \mathrm{of} \mathrm{pesticide}$ residuesin fruits and vegetables. J. Chromatogr ,A 1217:2548-2560.

Maddah, B. and M. Hasanzadeh (2017). Fe3O4/CNT Magnetic Nanocomposites as Adsorbents to Remove Organophosphorus Pesticides from Environmental Water., Int. J. Nanosci. Nanotechnol., 13: 139-149.

Makarov, V.V., S.S. Makarova, A.J. Love, O.V. Sinitsyna, A.O. Dudnik, I.V. Yaminsky, M.E. Taliansky and , N.O. Kalinina (2014). Biosynthesis of stable iron oxide nanoparticles in aqueous extracts of Hordeum vulgare and Rumex acetosa plants. Langmuir, 30, 5982-5988.[CrossRef] [PubMed]

Mittal, A. K., Y.Chisti and U. C. Banerjee (2013). Synthesis of metallic nanoparticles using plant extracts. Biotechnology Advances, 31(2), 346-356.

Morita, M., T Ueda, T. Yoneda, T. Koyanagi and T. Haga(2007) Flonicamid, a novel insecticide with a rapid inhibitory effect on aphid feeding Ishihara Sangyo Kaisha, Ltd, Central Research Institute, 2-3-1 Nishi-shibukawa, Kusatsu, Shiga 525-0025, Japan

Narayanan, K.B. and H.H. Park (2014). Antifungal activity of silver nanoparticles synthesized using turnip leaf extract (Brassica rapa L.) against wood rotting pathogens. European Journal of Plant Pathology, 140,185-192.

Philip, D., C.Unni, S. A. Aromal and V.Vidhu (2011). Murraya koenigii leafassisted rapid green synthesis of silver and gold nanoparticles. Spectrochimica Acta Part A: Molecular and Biomolecular Spectroscopy, 78(2), 899-904. 
Pillai, H. P. and K. Jesitha (2016) Nano-Phytotechnological Remediation of Endosulfan Using Zero Valent Iron Nanoparticles Journal of Environmental Protection. 7: 734-744.

Pyrzynska, K. (2011). Carbon nanotubes as sorbents in the analysis of pesticides. Chemosphere, 83: 1407-1413.

Radian, A. and Y. G. Mishael (2008). Characterizing and designing Polycation - clay nanocomposites as a basis for imazapyr controlled release formulations," Environmental Science and Technology, vol. 42, no. 5, pp. 1511-1516.

Rajak, V. K., N. V. Sunil Kumar, Thombre and A. Mandal (2018)..Chemical Engineering Communications, VOL. 205, NO. 7, 897-913.

Rao, A., A. Bankar, A.R. Kumar, S. Gosavi, and S. Zinjarde (2013). Removal of hexavalent chromium ions by Yarrowia lipolytica cells modified with phyto-inspired $\mathrm{Fe} 0 / \mathrm{Fe} 3 \mathrm{O} 4$ nanoparticles. J. Contam. Hydrol., 146, 63-73. [CrossRef] [PubMed]

Riu, J., A. Maroto, and F. X. Rius (2006). Nanosensors in environmental analysis", Talanta, 69: 288-301.

Rodriguez, J. M., A. J. Lopez and S. Bruque (1988).Interaction of phenamiphos with montmorillonite," Clays \& ClayMinerals, vol. 36, no. 3, pp. 284-288.

Romeh, A.A. and M.Y. Hendawi (2017). Biochemical interactions between Glycine max L. silicon dioxide ( $\mathrm{SiO} 2)$ and plant growth-promoting bacteria (PGPR) for improving phytoremediation of soil contaminated with fenamiphos and its degradation products. Pesticide Biochemistry and Physiology. 142, 32-43.

Salmana, J.M., V.O. Njokua,b and B.H. Hameed (2011). dsorption of pesticides from aqueous solution onto banana stalk activated Carbon .Chemical Engineering Journal 174 41- 48.

Sanchez Camazano, M. and M. J. Sanchez Martin (1983).Factors influencing interactions of organophosphorus pesticides with montmorillonite," Geoderma, vol. 29, no. 2, pp. 107-118.

Satapanajaru, T., P.Anurakpongsatorn, P. Pengthamkeerati and $\mathbf{H}$. Boparai (2008). Remediation of atrazine-contaminated soil and water by nano zerovalent iron, Water, Air, Soil Pollut., 192: 349-359.

Sayles, G. D., G. You, M. Wang and M. J. Kupferle (1997). DDT, DDD, and DDE dechlorination by zero-valent iron", Environ. Sci. Technol., 31: 3448-3454.

Shehata, N., M. S. El-Geundi, E. A. Ashour and R. Abobeah (2016). Structural Characteristics of the Egyptian Clay as a Low-Cost Adsorbent. Inter. J. Chem. Process Engineer. Res. 3(2): 35-45. 
Shi, L.N., X. Zhang and Z.L. Chen (2011).Removal of chromium (VI) from wastewater using bentonite-supported nanoscale zero-valent iron. Water Res. 45, 886.

Shu, H. T., D. Li, A. A. Scala and Y. H. Ma (1997).Adsorption of small organic pollutants from aqueous streams by aluminosilicate- based microporous materials," Separation and Purification Technology, 11(1): 27-36.

Sikdar, D., K. S. Katti and D. R. Katti (2008). Molecular interactions alter clay and polymer structure in polymer clay nanocomposites. Journal of nanoscience and nanotechnology. 8(4): 1638-1657.

Taghizade Firozjaee,T., N. Mehrdadi, M. Baghdadi and G. R. Nabi Bidhendi (2018) Application of Nanotechnology in Pesticides Removal from Aqueous Solutions - A review Int. J. Nanosci. Nanotechnol., Vol. 14, No. 1, March. 2018, pp. 43-56, 43.

Thompson, J. M., B. J. Chisholm and A. N. Bezbaruah, (2010). Reductive dechlorination of chloroacetanilide herbicide (alachlor) using zero-valent iron nanoparticles. Environ. Eng. Sci., 27: 227-232.

Tongpoothorn, W., M. Sriuttha, P. Homchan, S. Chanthai and C. Ruangviriyachai(2011). Preparation of activated carbon derived from Jatropha curcas fruit shell by simple thermo-chemical activation and characterization of their physico-chemical properties. Chem. Eng. Res. Des. 89, 335-340.

Torrents, A. and S. Jayasundera (1997).The sorption of nonionic pesticides onto clays and the influence of natural organic carbon," Chemosphere, 35(7): 1549-1565.

Trujillo -Reyes J., J.R. Peralta -Videa and J.L. Gardea -Torresdey (2014).Supported and unsupported nanomaterials for water and soil remediation: are they a useful solution for worldwide pollution? $J$. Hazard Mater. 280, 487.

Valente Nabais, J.M., C.E.C. Laginhas, P.J.M.Carrott and M.M.L. Ribeiro Carrott (2011). Production of activated carbons from almond shell. Fuel Process. Technol. 92, 234-240.

Wang, S., H. Sun, H.M. Ang and M.O. Tadé(2013). Adsorptive remediation of environmental pollutants using novel graphene-based nanomaterials. Chem. Eng. J. 226, 336.

Wang, W. (1986). Toxicity tests of aquatic pollutants by using Common duckweed. Environmental Pollution, 11(Series B), 1-14.

Yang, J. K.and Qiu (2010). Preparation of activated carbons from walnut shells via vacuum chemical activation and their application for methylene blue removal, Chem. Eng. J. 165 209-217. 
Yang, K. and B. Xing (2010). Adsorption of organic compounds by carbon nanomaterials in aqueous phase: Polanyi theory and its application, Chem. Rev., 110: 5989-6008.

Young-Soo, K. and X. Li. Qing (2003) Reduction of nitroaromatic pesticides with zero-valent iron. Chemosphere 54 (2004) 255-263.

Zadaka, D. S., A. Nir, Radian and Y. G. Mishael (2009).Atrazine removal from water by polycation-clay composites: effect of dissolved organic matter and comparison to activated carbon," Water Research,43(3): 677683.

\section{إستخدام تكنولوجيا النانو الخضراء والمعالجة النباتية في تنقية المياه

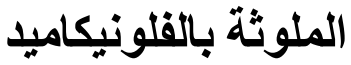

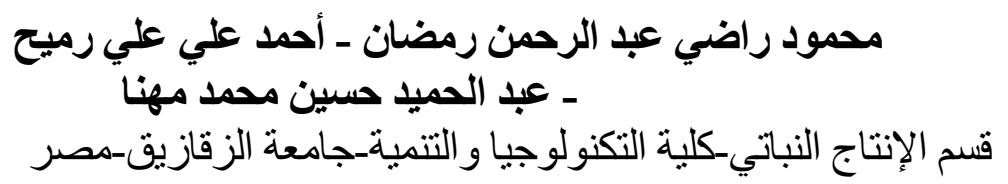

تم إزالة مبيد الفلومنيكاميد من الماء بإستخدام معدن البينتونايت والفحم النشط و أيضا إستخدام

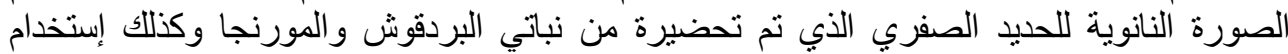

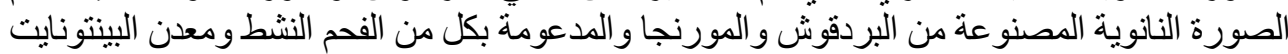

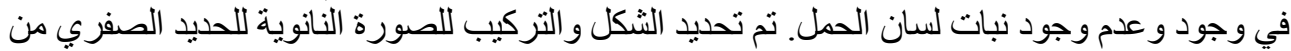

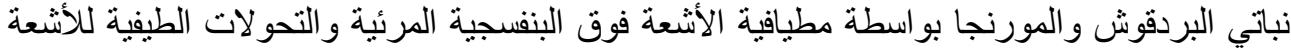

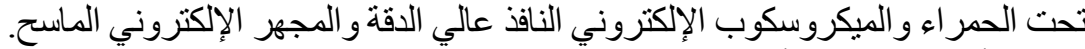

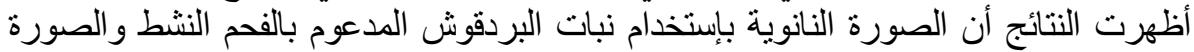

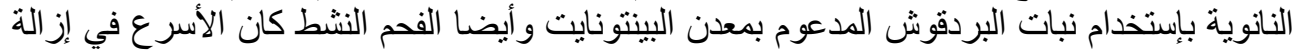

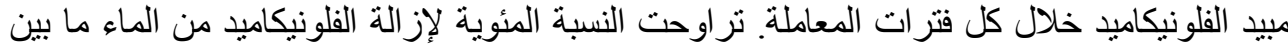

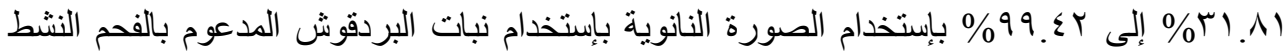

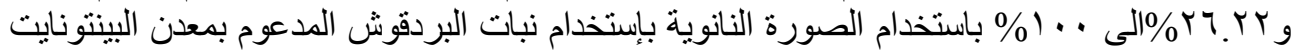

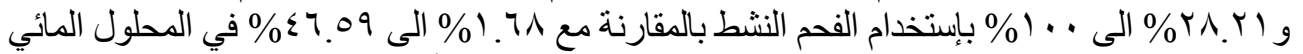

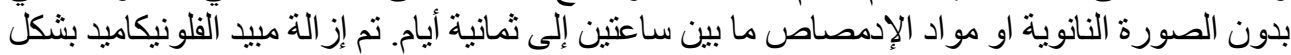

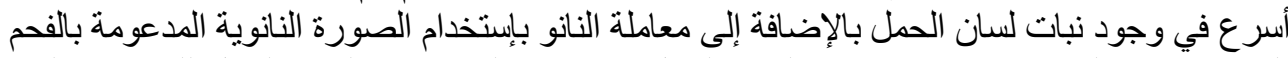

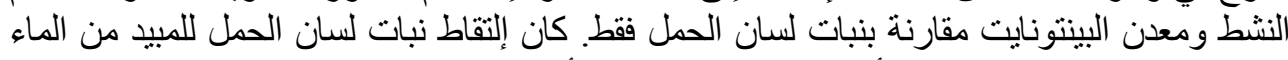

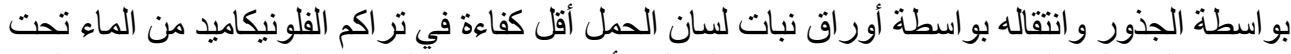

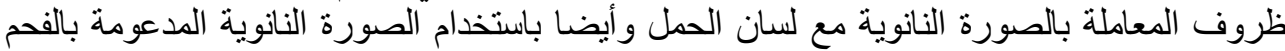

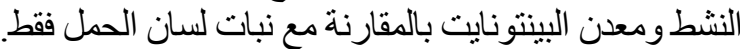

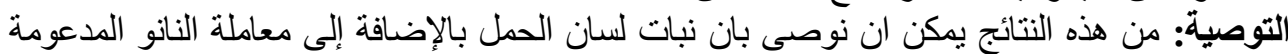

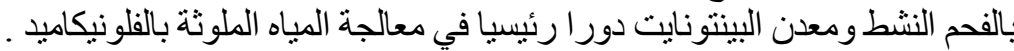

